\title{
Non-toxic Efficacy of the Combination of Caffeine and Valproic Acid on Human Osteosarcoma Cells In Vitro and in Orthotopic Nude-mouse Models
}

\author{
KENTARO IGARASHI ${ }^{1,2,3}$, NORIO YAMAMOTO ${ }^{3}$, KATSUHIRO HAYASHI $^{3}$, AKIHIKO TAKEUCHI $^{3}$, \\ HIROAKI KIMURA $^{3}$, SHINJI MIWA $^{3}$, ROBERT M. HOFFMAN ${ }^{1,2}$ and HIROYUKI TSUCHIYA ${ }^{3}$ \\ ${ }^{1}$ AntiCancer, Inc., San Diego, CA, U.S.A.; \\ ${ }^{2}$ Department of Surgery, University of California, San Diego, CA, U.S.A.; \\ ${ }^{3}$ Department of Orthopaedic Surgery, Kanazawa University, Kanazawa, Japan
}

\begin{abstract}
Background/Aim: We have previously reported that caffeine can enhance chemotherapy efficacy of bone and softtissue sarcoma via cell-cycle perturbation. Valproic acid has histone deacetylase (HDAC) inhibitory activity. The present study aimed to investigate the efficacy of the combination of valproic acid and caffeine on human osteosarcoma cells in vitro and in orthotopic nude-mouse models. Materials and Methods: Human osteosarcoma cell lines (MG63, 143B and SaOS2) were used. Cell survival after a $72 \mathrm{~h}$ exposure to valproic acid and caffeine was assessed with a WST-8 assay. Half maximal inhibitory concentration $\left(I C_{50}\right)$ values and combination indices (CIs) were calculated. Caspase 3 activity was measured by a fluorochrome inhibitor of caspase (FLICA) assay. 143B cells were also transplanted to the tibia of nude mice and treated with these drugs. Results: Both valproic acid and caffeine caused concentration-dependent cell death of the osteosarcoma cell lines in vitro. Apoptosis induction was observed with the Caspase 3 assay. The combination was synergistic. The combination of valproic acid and caffeine showed effective anti-tumor activity in vivo without the need for conventional anticancer drugs or any observable toxicity Conclusion: Efficacy of combination therapy with caffeine and valproic acid in osteosarcoma was observed in vitro and in vivo without toxicity, suggesting that
\end{abstract}

This article is freely accessible online.

Correspondence to: Robert M. Hoffman, Ph.D., AntiCancer, Inc., 7917 Ostrow Street, San Diego, CA 92111, U.S.A. Tel: +1 8586542555, Fax: +18582684175, e-mail: all@anticancer.com or Hiroyuki Tsuchiya, MD, Ph.D., Department of Orthopaedic Surgery, Kanazawa University, Kanazawa, Japan. Tel: +81 762652374, Fax: +81 762344261, e-mail: tsuchi@med.kanazawa-u.ac.jp

Key Words: Osteosarcoma, caffeine, varproic acid, histone deacetylase, inhibitor, in vitro, nude mice, orthotopic. either or both drugs can be effectively combined with appropriate chemotherapy in the future.

Osteosarcoma is a common malignant primary bone tumor occurring predominantly in children and young adults. Osteosarcoma has a 5-year survival rate that can exceed $70 \%$ in patients treated with surgery and chemotherapy (1$3)$, including methotrexate, cisplatin, doxorubicin and ifosfamide. However, dose escalation of chemotherapy has not improved the outcome (4). Since survival of patients with osteosarcoma has plateaued during the last decade, more effective treatment approaches are needed. Many interesting new biological approaches to therapy are being investigated, most of which involve adding new drugs or other new therapies to existing chemotherapy protocols (5).

Caffeine (1,3,7-trimethylxanthine) is a natural stimulatory compound that is present in many plants, including coffee beans and tea leaves (6). Caffeine has anti-tumor effects (7), such as apoptosis induction (8). Caffeine can also overcome chemotherapy- or radiation-induced delays in cell cycle progression $(9,10)$, thereby enhancing their efficacy $(11,12)$.

We have previously reported that caffeine-modulation chemotherapy improved the treatment of bone and soft tissue sarcoma in the clinic (13-18).

Modulation of the cell cycle by caffeine was visualized using time-lapse imaging of HeLa cells expressing a fluorescent ubiquitination-based cell cycle indicator (FUCCI). Clonogenic assays showed that caffeine increased the inhibition by cisplatinum (CDDP) on cell proliferation. The combination of CDDP and caffeine enhanced mitosis and, thereby subsequently increased apoptosis. Time-lapse imaging showed that CDDP induced cell-cycle arrest in the $\mathrm{S} / \mathrm{G}_{2}$ phase in HeLa-FUCCI cells and that caffeine overcame the cell-cycle arrest, thereby increasing its efficacy (12).

Valproic acid, a short chain fatty acid that is widely used to treat epilepsy, has been reported to be a potent histone 

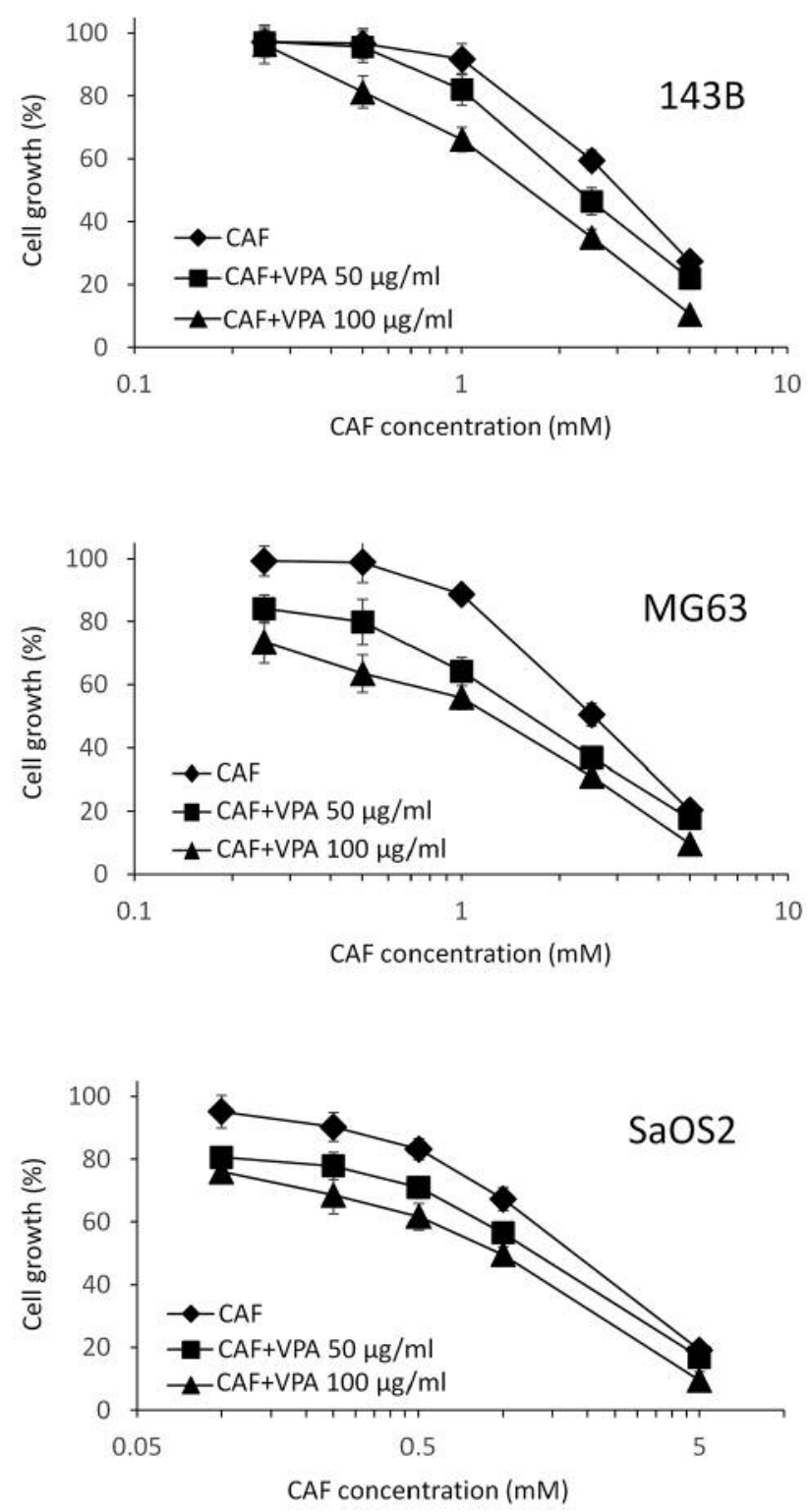

Figure 1. Growth inhibitory activity of caffeine $(C A F)$ and valproic acid (VPA) or their combination against 143B, MG63 and SaOS2 osteosarcoma cells. Osteosarcoma cells were incubated with each drug or their combination for $72 \mathrm{~h}$. Viability was determined with the WST-8 assay. Experimental details are provided in the Materials and Methods section.

deacetylase (HDAC) inhibitor. Histone deacetylase (HDAC) inhibitors can induce apoptosis, cell differentiation, autophagy and are anti-angiogenic (19). Clinical studies of valproate include treatment of myelodysplastic syndrome (20), melanoma (21) and solid tumors (22).

In the present study, we evaluated the combination efficacy of caffeine and valproic acid in osteosarcoma in vitro and in vivo.
Table I. Half maximal inhibitory concentration $\left(I C_{50}\right)$ values of caffeine $(C F)$ and valproic acid (VPA) alone and in combination.

\begin{tabular}{llll}
\hline & \multicolumn{3}{c}{ CAF IC $_{50}(\mathrm{mM})$} \\
\cline { 2 - 4 } Cell lines & & + VPA $50 \mu \mathrm{g} / \mathrm{ml}$ & + VPA $100 \mu \mathrm{g} / \mathrm{ml}$ \\
\hline 143B & $1.96 \pm 0.15$ & $0.94 \pm 0.08^{* *}$ & $0.71 \pm 0.03^{* *}$ \\
MG63 & $1.52 \pm 0.13$ & $0.70 \pm 0.08^{* *}$ & $0.53 \pm 0.07^{* *}$ \\
SaOS2 & $1.74 \pm 0.15$ & $1.24 \pm 0.14^{* *}$ & $0.88 \pm 0.10^{* *}$ \\
\hline
\end{tabular}

IC50 values for 143B, MG63 and SaOS2 osteosarcoma cells treated with caffeine $(50 \mu \mathrm{g} / \mathrm{ml})$ and valproic acid $(100 \mu \mathrm{g} / \mathrm{ml})$ or their combination. Osteosarcoma cells were incubated with each drug for 72 $\mathrm{h}$ and then assessed with the WST-8 assay. Experimental details are provided in the Materials and Methods section. ${ }^{*} \mathrm{P}<0.0001$.

\section{Materials and Methods}

Drugs. Valproic acid was obtained from Sigma Aldrich Co., Ltd. (St. Louis, MO, USA). Caffeine was obtained from Wako Pure Chemical Industries, Ltd. (Osaka, Japan).

Cell lines and growth conditions. The osteosarcoma cell lines MG63, 143B and SaOS2 were obtained from the American Type Culture Collection (Rockville, MD, USA). All cells were grown in RPMI-1640 medium (Fisher Scientific, Santa Ana, CA) supplemented with $10 \%$ fetal bovine serum, $100 \mathrm{U} / \mathrm{ml}$ penicillin and $100 \mu \mathrm{g} / \mathrm{ml}$ streptomycin. Cells were kept in log phase by supplementation with fresh medium 2-3 times/week.

Growth inhibition assay. Cellular viability was assessed using the WST-8 dye (2-(2-methoxy-4-nitrophenyl)-3-(4-nitrophenyl)-5-(2,4disulfophenyl)-2H-tetrazolium) reduction assay (Dojindo, Kumamoto, Japan). Briefly, cells were seeded in 96-well flatbottomed microplates $\left(5 \times 10^{4}\right.$ cells $\left./ \mathrm{ml}\right)$, incubated at $37^{\circ} \mathrm{C}$ for $24 \mathrm{~h}$ and exposed to various concentrations of tested compounds for 72 h. For each concentration, at least 8 wells were used. After incubation with the test compounds, $10 \mu \mathrm{l}$ WST- 8 solution was added to each well. The microplates were further incubated for $3 \mathrm{~h}$ at $37^{\circ} \mathrm{C}$ and absorption was measured using a microprocessorcontrolled microplate reader (iMarkTM; Bio-Rad Laboratories, Hercules, CA, USA) at $450 \mathrm{~nm}$. The cell-survival fraction was calculated as the percentage of untreated control cells and half maximal inhibitory concentration $\left(\mathrm{IC}_{50}\right)$ values were derived.

Calculation of combination index $(C I)$. The specific interaction between caffeine and valproic acid on osteosarcoma cell lines was evaluated with the combination index (CI) assay using the CalcuSyn software from ComboSyn Inc. (Paramus, NJ, USA) (23). Synergy is defined as a $\mathrm{CI}<1.0$, antagonism as a $\mathrm{CI}>1.0$ and additivity as CI values not significantly different from 1.0.

Caspase 3 assay. 143B cells were seeded in 24-well flat-bottomed microplates at $5 \times 10^{4}$ cells $/ \mathrm{ml}$, incubated at $37^{\circ} \mathrm{C}$ for $24 \mathrm{~h}$ and exposed to various concentrations of tested compounds for $24 \mathrm{~h}$ and $48 \mathrm{~h}$. The cultures were rinsed with PBS-EDTA and then incubated at $37^{\circ} \mathrm{C}$ for 1 $\mathrm{h}$ in RPMI-1640 with 10\% FBS. A FLICA solution (Immunochemistry 

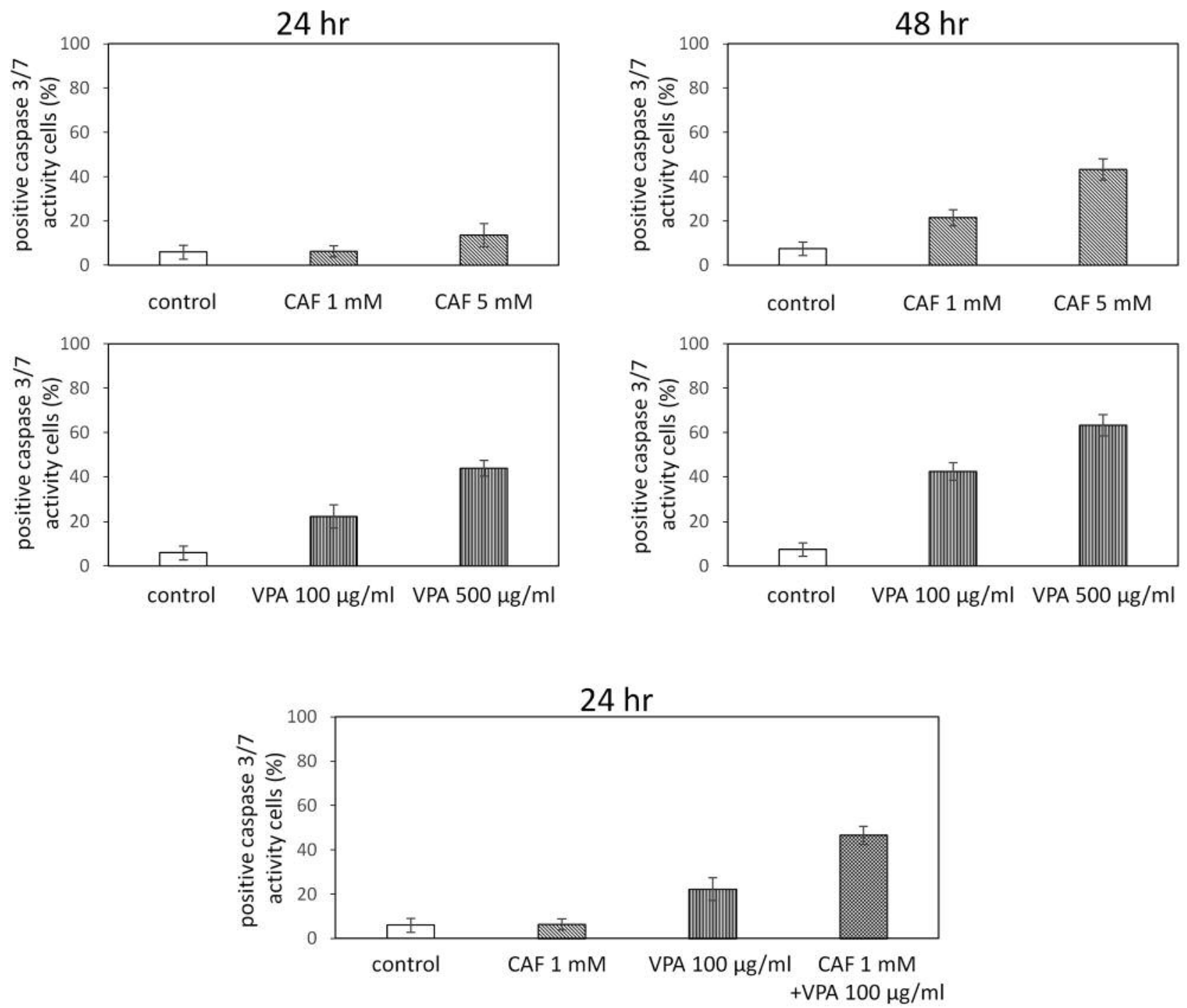

Figure 2. Caspase 3/7 activity induced by caffeine, valproic acid or their combination on 143B osteosarcoma cells. Percentage of Caspase 3/7 positive cells was determined. Experimental details are provided in the Materials and Methods section.

Technologies, LLC, Bloomington, MN, USA) was added to the cultures and incubated an additional $1 \mathrm{~h}$. Fluorescence was detected with the Power IX71 microscope (Olympus Corp., Tokyo, Japan). Three random fields, each containing at least 100 cells, were examined at $\times 100$ magnification.

Orthotopic mouse model.

Mice: Female nude mice (BALB/c-nu/nu) aged 4-6 weeks were purchased from Sankyo Laboratory Inc. (Toyama, Japan) and housed in a barrier facility under high-efficiency particulate arrestance (HEPA) filtration. The mice were bred under germ-free and specific pathogen-free conditions. All animal studies were conducted in accordance with the principles and procedures outlined in the Kanazawa University's guidelines for the care and use of laboratory animals and national laws on the care and use of laboratory animals.
Intra-tibial $143 \mathrm{~B}$ transplantation: A suspension of cells $\left(2 \times 10^{5}\right.$ $143 \mathrm{~B}$ in Matrigel) was implanted in the tibia of nude mice. The mice were anesthetized with phentobarbital sodium $(40 \mathrm{mg} / \mathrm{kg})$ and an incision was placed for a tibial exposure. A pin hole was placed in the proximal tibia and $10 \mu \mathrm{l}$ cell suspension was implanted through the pin hole using a 23-gauge needle. All mice were examined daily; tumors were measured twice weekly using digital calipers; and mice were weighed. One week after transplantation, mice were treated intraperitoneally (i.p.) with caffeine $(100 \mathrm{mg} / \mathrm{kg})$, valproic acid $(500 \mathrm{mg} / \mathrm{kg})$ and normal saline $(\mathrm{n}=8 \mathrm{each})$. Treatments were repeated five times a week for four weeks. Six weeks after transplantation, all mice were sacrificed.

Measurement of primary tumor growth. The tumors were allowed to form and leg dimensions were measured weekly. Tumor volumes 
Table II. Combination index (CI) value of the combination of caffeine (CAF) and valproic acid VPA).

\begin{tabular}{|c|c|c|c|c|c|c|c|c|c|}
\hline \multirow[b]{2}{*}{$\mathrm{CAF}(\mathrm{mM})$} & \multirow[b]{2}{*}{$\mathrm{VPA}(\mu \mathrm{g} / \mathrm{ml})$} & \multicolumn{3}{|c|}{$\mathrm{Cl}$} & \multirow[b]{2}{*}{$\mathrm{CAF}(\mathrm{mM})$} & \multirow[b]{2}{*}{$\mathrm{VPA}(\mu \mathrm{g} / \mathrm{ml})$} & \multicolumn{3}{|c|}{$\mathrm{Cl}$} \\
\hline & & 143B & MG63 & $\mathrm{SaOS} 2$ & & & 143B & MG63 & $\mathrm{SaOS} 2$ \\
\hline 0.1 & 50 & & & 0.84972 & 0.1 & 100 & & & 1.19036 \\
\hline 0.25 & 50 & 1.11145 & 0.68632 & 1.00805 & 0.25 & 100 & 1.35178 & 0.79334 & 1.05323 \\
\hline 0.5 & 50 & 1.4148 & 0.75329 & 1.07205 & 0.5 & 100 & 0.77327 & 0.71363 & 1.04497 \\
\hline 1 & 50 & 0.99097 & 0.72463 & 0.99968 & 1 & 100 & 0.75811 & 0.79913 & 0.98349 \\
\hline 2.5 & 50 & 0.81052 & 0.84937 & & 2.5 & 100 & 0.70529 & 0.84814 & \\
\hline 5 & 50 & 0.76739 & 0.99667 & & 5 & 100 & 0.5117 & 0.76369 & \\
\hline
\end{tabular}

CI values were calculated in each combination ratio. CI values of $<1,1$ or $>1$ indicate synergy, additivity or antagonism, respectively.

were calculated using the following equation: volume $=4 \pi$ $(\mathrm{A} / 2)(\mathrm{B} / 2)(\mathrm{C} / 2) / 3$, where $\mathrm{A}$ is the width (average distance in the medial-lateral plane), $\mathrm{B}$ is the length (average distance in the proximal-distal plane) and $\mathrm{C}$ is the width (average distance in the anterior-posterior plane).

Statistical analysis. Data are presented as means \pm standard deviation and were compared between groups using the unpaired Student's $t$ test. A $p<0.05$ value was considered statistically significant.

\section{Results}

Cytotoxicity. The cytotoxic activity of caffeine and valproic acid was determined for 143B, MG63 and SaOS2 osteosarcoma cell lines in vitro. Each compound significantly inhibited osteosarcoma cell growth in a dose-dependent manner (Figure 1). Addition of 50 and $100 \mu \mathrm{g} / \mathrm{ml}$ of valproic acid in combination with caffeine enhanced inhibition of all osteosarcoma cell lines (Figure 1, Table I).

Combination effect of caffeine and valproic acid on osteosarcoma cells. A synergistic interaction between caffeine and valproic acid was observed for 143B and MG63 cells (Figure 1). The CI values were significantly $<1$ and indicated synergy at all tested concentrations in the MG63 cell line (Table II). In the 143B cell line, synergy was observed at caffeine concentration of $1 \mathrm{mM}$ or higher. An additive effect was observed for the SaOS2 cell line. Thus, a synergistic or additive effect for the combination of caffeine and valproic acid in the three osteosarcoma cell lines was observed.

Caspase 3 assay. Caffeine and valproic acid alone and in combination induced a high caspase activity and higher activity at lower concentrations in combination, compared with mono-therapy (Figure 2).

Efficacy of valproic acid and caffeine in an orthotopic mouse model of osteosarcoma. The orthotopic 143B tumor was

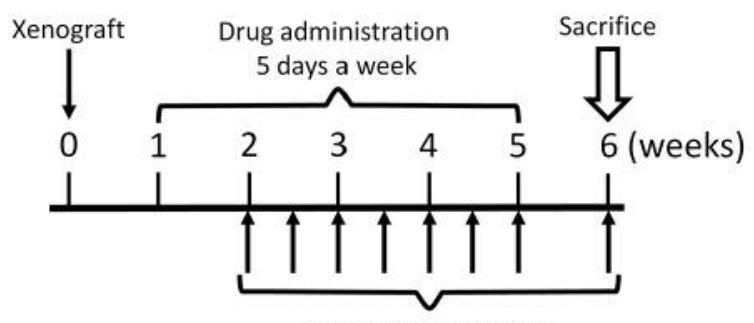

Tumor measurement

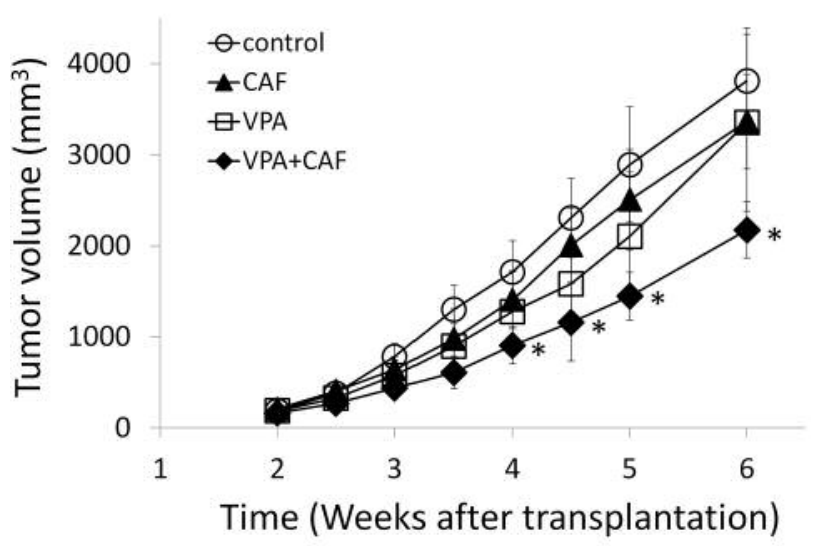

Figure 3. In vivo antitumor efficacy of caffeine $(C A F)$ and valproic acid (VPA). 143B cells were orthotopically transplanted into the tibia of nude mice and allowed to form tumors. Mice were treated with caffeine or valproic acid or the combination, i.p. (caffeine $(100 \mathrm{mg} / \mathrm{kg})$, valproic acid (500 mg/kg), five times a week for four weeks). Tumor volume was measured at the indicated time points after the onset of treatment. $n=8$ mice/group.

treated with caffeine and/or valproic acid combination of caffeine and valproic acid was more effective than either compound alone (combination vs. control: $p=1.66 \times 10^{-7}$; combination $v s$. valproic acid: $p=6.55 \times 10^{-5}$; combination $v s$. caffeine: $p=0.001)$. There were no animal deaths in any group (Figure 3). 


\section{Discussion}

In the present study, efficacy of caffeine and valproic acid against oseteosarcoma was evaluated alone and in combination. Monotherapy was dose-dependently effective against osteosarcoma cells. Combination therapy had greater efficacy against all osteosarcoma cell lines and was synergistic for two of them. Each agent induced apoptosis in a dose- and timedependent manner. Combination therapy induced apoptosis at lower concentration compared to monotherapy. In the orthotopic mouse model, though caffeine and valproic acid monotherapy did not significantly inhibit tumor growth, the combination had a significant decrease in tumor volume compared with the untreated control group or either drug alone. These results indicate that caffeine and valproic acid could be a potent therapeutic combination, possibly with a first-line chemotherapy regimen. Future studies could take advantage of the cell-cycle perturbation effects of caffeine by combining them with the tumor-specific cell-cycle effects of methionine depletion (24-27).

\section{Conflicts of Interest}

The Authors have no conflicts of interest to disclose.

\section{References}

1 Isakoff MS, Bielack SS, Meltzer $\mathrm{P}$ and Gorlick R: Osteosarcoma: Current treatment and a collaborative pathway to success. J Clin Oncol 33: 3029-3035, 2015.

2 Bacci G, Ferrari S, Lari S, Mercuri M, Donati D, Longhi A, Forni C, Bertoni F, Versari M and Pignotti E: Osteosarcoma of the limb: amputation or limb salvage in patients treated by neoadjuvant chemotherapy. J Bone Joint Surg Br 84: 88-92, 2002.

3 Muscolo DL, Ayerza MA, Aponte-Tinao LA and Ranalletta M: Partial epiphyseal preservation and intercalary allograft reconstruction in high-grade metaphyseal osteosarcoma of the knee. J Bone Joint Surg Am 86: 2686-2693, 2002.

4 Lewis VO: What's new in musculoskeletal oncology. J Bone Joint Surg Am 89: 1399-1407, 2007.

5 Arpaci F, Ataergin S, Ozet A, Erler K, Basbozkurt M, Ozcan A, Komurcu S, Ozturk B, Celasun B, Kilic S and Kuzhan O: The feasibility of neoadjuvant high-dose chemotherapy and autologous peripheral blood stem cell transplantation in patients with nonmetastatic high grade localized osteosarcoma: results of a phase II study. Cancer 104: 1058-1065, 2005.

6 Coffee, tea, mate, methylxanthines and methylglyoxal, IARC working group on the evaluation of carcinogenic risks to humans. Lyon, 27 February to 6 March 1990. IARC Monogr Eval Carcinog Risks Hum 51: 1-513, 1991.

7 Levi-Schaffer F and Touitou E: Xanthines inhibit 3T3 fibroblast proliferation. Skin Pharmacol 4: 286-290, 1991.

8 He Z, Ma WY, Hashimoto T, Bode AM, Yang CS and Dong Z: Induction of apoptosis by caffeine is mediated by the p53, Bax, and caspase 3 pathways. Cancer Res 63: 4396-4401, 2003.

9 Tolmach LJ, Jones RW and Busse PM: The action of caffeine on $\mathrm{x}$-irradiated Hela cells. I. Delayedinhibition of DNA synthesis. Radiat Res 71: 653-665, 1977.
10 Lau CC and Pardee AB: Mechanism by which caffeine potentiates lethality of nitrogen mustard. Proc Natl Acad Sci USA 79: 2942-2946, 1982.

11 Tolmach LJ, Jones RW and Busse PM: The action of caffeine on $\mathrm{x}$-irradiated Hela cells. I. Delayed inhibition of DNA synthesis. Radiat Res 71: 653-665, 1977.

12 Miwa S, Yano S, Tome Y, Sugimoto N, Hiroshima Y, Uehara F, Mii S, Kimura H, Hayashi K, Efimova EV, Fujiwara T, Tsuchiya $\mathrm{H}$ and Hoffman RM: Dynamic color-coded fluorescence imaging of the cell-cycle phase, mitosis, and apoptosis demonstrates how caffeine modulates cisplatinum efficacy. J Cell Biochem 114: 2454-2460, 2013.

13 Karita M, Tsuchiya H, Yamamoto N, Shirai T, Hayashi K and Nishida H: Caffeine-potentiated chemotherapy for clear cell sarcoma: a report of five cases. Int J Clin Oncol 18(1): 33-37, 2013.

14 Kimura H, Tsuchiya H, Shirai T, Nishida H, Hayashi K, Takeuchi A, Ohnari I and Tomita K: Caffeine-potentiated chemotherapy for metastatic osteosarcoma. J Orthop Sci 14: 556-565, 2009 .

15 Kawahara M, Takahashi Y, Takazawa K, Tsuchiya H, Tomita K, Yokogawa K and Miyamoto K: Caffeine dose-dependently potentiates the antitumor effect of cisplatin on osteosarcomas. Anticancer Res 28: 1681-1685, 2008.

16 Tsuchiya H, Tomita K, Mori Y, Asada N and Yamamoto N: Marginal excision for osteosarcoma with caffeine assisted chemotherapy. Clin Orthop 358: 27-35, 1999.

17 Tsuchiya H, Yasutake H, Yokogawa A, Baba H, Ueda Y and Tomita K: Effect of chemotherapy combined with caffeine for osteosarcoma. J Cancer Res Clin Oncol 118: 567-569, 1992.

18 Tsuchiya H, Tomita K, Mori Y, Asada N, Morinaga T, Kitano S and Yamamoto N: Caffeine-assisted chemotherapy and minimized tumor excision for nonmetastatic osteosarcoma. Anticancer Res 18: 657-666, 1998.

19 Marks PA: The clinical development of histone deacetylase inhibitors as targeted anticancer drugs. Expert Opin Investig Drugs 19: 1049-1066, 2010.

20 Raffoux E, Cras A, Recher C, Boëlle PY, de Labarthe A, Turlure P, Marolleau JP, Reman O, Gardin C, Victor M, Maury S, Rousselot P, Malfuson JV, Maarek O, Daniel MT, Fenaux P, Degos L, Chomienne C, Chevret S and Dombret H: Phase 2 clinical trial of 5-azacitidine, valproic acid, and all-trans retinoic acid in patients with high-risk acute myeloid leukemia or myelodysplastic syndrome. Oncotarget 1: 34-42, 2010.

21 Rocca A, Minucci S, Tosti G, Croci D, Contegno F, Ballarini M, Nolè F, Munzone E, Salmaggi A, Goldhirsch A, Pelicci PG and Testori A: A phase I-II study of the histone deacetylase inhibitor valproic acid plus chemoimmunotherapy in patients with advanced melanoma. Br J Cancer 100: 28-36, 2009.

22 Munster P, Marchion D, Bicaku E, Lacevic M, Kim J, Centeno B, Daud A, Neuger A, Minton S and Sullivan D: Clinical and biological effects of valproic acid as a histone deacetylase inhibitor on tumor and surrogate tissues: phase I/II trial of valproic acid and epirubicin/FEC. Clin Cancer Res 15: 24882496, 2009.

23 Chou TC and Martin N: CompuSyn for Drug Combinations: PC Software and User's Guide: A Computer Program for Quantitation of Synergism and Antagonism in Drug Combinations, and the Determination of $\mathrm{IC}_{50}$ and $\mathrm{ED}_{50}$ and $\mathrm{LD}_{50}$ Values, ComboSyn Inc, Paramus, (NJ), 2005. 
24 Hoffman RM and Jacobsen SJ: Reversible growth arrest in simian virus 40 transformed human fibroblasts. Proc Natl Acad Sci USA 77: 7306 7310, 1980.

25 Yano S, Li S, Han Q, Tan Y, Bouvet M, Fujiwara T and Hoffman RM: Selective methioninase-induced trap of cancer cells in $\mathrm{S} / \mathrm{G} 2$ phase visualized by FUCCI imaging confers chemosensitivity. Oncotarget 5: 8729-8736, 2014.

26 Yano S, Takehara K, Zhao M, Tan Y, Han Q, Li S, Bouvet M, Fujiwara T and Hoffman RM: Tumor-specific cell-cycle decoy by Salmonella typhimurium A1-R combined with tumorselective cell-cycle trap by methioninase overcome tumor intrinsic chemoresistance as visualized by FUCCI imaging. Cell Cycle 6: 1-9, 2016.

27 Guo H, Lishko VK, Herrera H, Groce A, Kubota T and Hoffman RM: Therapeutic tumor specific cell cycle block induced by methionine starvation in vivo. Cancer Res 53: 5676 5679, 1993.

Received June 30, 2016

Revised July 25, 2016

Accepted August 2, 2016 